\title{
AZ ÖKOLÓGIAI FENNTARTHATÓSÁG ÉS A REGIONÁLIS VERSENYKÉPESSÉG ÖSSZEFÜGGÉSEI
}

\author{
(Connections between Ecologic Sustainability and Regional \\ Competitiveness)
}

\section{MÁLOVICS GYÖRGY - VÁN HAJNALKA}

\section{Kulcsszavak:}

regionális versenyképesség természeti töke ökoszisztéma-szolgáltatások

Számos európai uniós és nemzeti dokumentum középpontjában célként a versenyképesség, és ezzel párhuzamosan - illetve inkább a tartós versenyképesség növelésének meg nem kerülhetö kereteként - a fenntarthatóság áll. A közvélemény és a kömyezeti problémakörrel foglalkozó kutatók körében napjainkra egyaránt tudatosult, hogy a versenyképesség oly módon történõ növelése, amely a természeti tôke túlzott mértékü felhasználása által valósul meg, kontraproduktiv lehet - azaz beszükiti a jövőbeni társadalmi-gazdasági választási lehetôségeket. Ezen álláspont föleg a klimaváltozással vagy a biodiverzitás csökkenésével kap csolatos közéleti, politikai és tudományos vitákban igen gyakran felmerül.

Tanulmányunkban a természet-gazdaság viszony és területi aspektusainak szakirodalmi elemzése alapján rávilágitunk a természeti töke és a regionális versenyképesség kapcsolatának legfontosabb alapvonásaira. Elöször megvizsgáljuk az ökológiai rendszerek és a gazdasági rendszer összefüggéseivel kapcsolatos specifikus tudományos eredményeket, amelyek kapcsolódhatnak a versenyképesség problémaköréhez. Ezt követöen elemezzük, hogy e szakirodalmi eredmények milyen mértékben ,épültek be" egyes olyan közgazdaságtani irányzatokba (neoklasszikus közgazdaságtan, fejlödés-gazdaságtan, új intézményi közgazdaságtan, evolucionista közgazdaságtan és a verseny ủj közgazdaságtana), amelyek mind a regionális versenyképességgel, mind pedig a természet gazdasági folyamatban betöltött szerepével kapcsolatosan lényeges mondanivalóval rendelkeznek. Bár a vizsgált irányzatok számos szempontból releváns szempontokat vetnek fel a természeti tóke, illetve regionális versenyképesség vonatkozásában, mégis a két gondolatkör viszonyának tárgyalása jellemzöen meglehetôsen elnagyolt és alapvetốn igen elhanyagolt.

\section{Bevezetés}

A társadalmi-gazdasági rendszer jelenlegi folyamatai „fenntarthatatlanságának" tényét, azok ökológiai, társadalmi, és így végső soron gazdasági szempontból is önpusztító jellegét a Bruntland-jelentés (1987) tette szélesebb körben ismertté. Azóta képezi a „fenntartható fejlődés” fogalma egyre inkább a mindenkori médiabeli, politikai és tudományos diskurzus ${ }^{1}$ integráns részét. A Bruntland-jelentés egyik fó mondanivalóját, társadalmi-gazdasági rendszerünk ökológiai szempontból való fenntarthatatlanságát napjainkban - sok egyéb dokumentum mellett - az IPCC (2007) és a Stern (2006) jelentések is alátámasztják.

A téma vizsgálata azért is különösen fontos, mert a fenntarthatóság mellett szintén deklarált és széles körben elfogadott cél a kiegyensúlyozott regionális fejlödés 
Az ökológiai fenntarthatóság és a regionális versenyképesség összefüggései.

Tér és Társadalom 22. évf. 2008/2. 21-40. p.

megvalósítása, ennek eszköze pedig a regionális versenyképesség javítása ( $E C$ 1999; 2005). A regionális versenyképesség növelésének, illetve az ezzel foglalkozó dokumentumoknak konkrét - adott esetben a célhierarchiában a fenntarthatóság felett álló - célja gazdaságfejlesztési beavatkozások megfogalmazása. Elvileg ez a gondolkodásmód jelenik meg az Európai Területfejlesztési Perspektívában is ( $E C$ 1999), amely a területfejlesztés három alapvető célját is megfogalmazza:

- gazdasági és társadalmi kohézió (méltányosság),

- a természeti erőforrások és a kulturális örökség megörzése (fenntarthatóság), és

- az európai térség kiegyenlítettebb versenyképessége (hatékonyság).

A versenyképesség egyik általánosan elfogadott, ún. „egységes” definíciója 1999-ben a Hatodik Periodikus Jelentésben jelent meg, mely szerint (EC 1999, 75): „a vállalatok, iparágak, régiók, nemzetek és nemzetek feletti régiók képessége relatíve magas jövedelem és relative magas foglalkoztatottsági szint tartós létrehozására, miközben a külgazdasági (globális) versenynek ki vannak téve". Ezen definíció alapján a „területi egységek akkor versenyképesek, ha gazdaságuk nyitott és az egy lakosra jutó jövedelmük tartósan magas és növekvő, valamint magas szintủ és nem csökkenő a foglalkoztatottsági ráta, azaz ebböl a jövedelemből a lakosság széles rétegei is várhatóan részesülnek" (Lengyel 2003, 279).

A régiók versenyképessége manapság egyre népszerübb kutatási terület, a fogalom „a modern kapitalista gazdaság természeti törvényévé vált” (Kitson et al 2004, 991). Az egyes régiók versenyképességének meghatározását és az azt növelö politikák kidolgozását sok országban (USA, Nagy-Britannia, Japán, Olaszország, Hollandia stb.) hivatalosan intézményesítették, az EU megújult lisszaboni stratégiájának fơ célja is a gazdasági növekedés és foglalkoztatás, lényegében a versenyképesség növelése. Ugyanakkor a gyorsan bővülö szakirodalom ellenére még mindig nincs egy általánosan elfogadott elméleti vagy gyakorlati keret a regionális versenyképesség értelmezésére, mérésére, vagy a regionális versenyképesség és a gazdasági prosperitás közti kapcsolat vizsgálatára - azaz a regionális versenyképesség mindmáig egy eléggé nehezen megfogható koncepciónak tekinthető (Gardiner et al 2004; Kitson et al 2004; Turok 2004).

A régiók versenyképessége mindenesetre magában foglalja a régión belüli életszínvonal tartós emelését, a jólét növekedését. Az egységes fogalomból dekompozíciós eljárással származtatható három közgazdasági kategória, amelyek a regionális versenyképességet mérhetóvé teszik (Lengyel 2000): magas és növekvő gazdasági kibocsátás ${ }^{2}$, és ezzel kapcsolatban magas és növekvő munkatermelékenység, valamint magas és növekvő foglalkoztatottság. A munkatermelékenységet alapvetóen az egy foglalkoztatottra (egy ledolgozott munkaórára) jutó GDP határozza meg, a foglalkoztatottságot pedig a munkaképes korú lakosságon belül a foglalkoztatottak aránya mutatja.

A fentiek alapján a regionális versenyképesség két mérhető közgazdasági kategóriája, egyúttal két, egymással néha ellentétesen ható optimalizálni kívánt tényezője: a munkatermelékenység és a foglalkoztatottság. A természeti töke ${ }^{3}$ regionális ver- 
senyképességre gyakorolt hatásának elemzése, a regionális versenyképesség ezen két kategóriájának és a természeti tőkének a kapcsolata bonyolult és kellően nem tisztázott kérdéseket vet fel. Ennek legföbb oka, hogy a szakirodalomban meglehetősen kevés információt találhatunk a természet állapotváltozása és a foglalkoztatottság kapcsolatảról. Már jóval kidolgozottabbak az ökológiai rendszer és a regionális versenyképesség termelékenységi dimenziójának összefüggései. Bár a regionális termelékenység és versenyképesség nem azonos fogalmak - furcsa lenne például versenyképesnek nevezni egy olyan térséget, ahol a termelékenységnövekedés a foglalkoztatottság visszaesésével jár, és így magas munkanélküliségi ráta mellett valósul meg -, a termelékenység mindenképpen kulcsfogalom a regionális versenyképességben. Nem feledve a foglalkoztatás szerepét, tanulmányunk következỏ részében, amely kifejezetten a természeti tőke gazdasági folyamatban betöltött szerepét elemzi, elsősorban a természeti tőke és a termelékenység kapcsolatával foglalkozunk.

A regionális fejlödés lényege az ott élők jólétének, életszínvonalának, életminöségének javulása, melynek eszköze a versenyképesség növelése. A közgazdaságtanban ennek kapcsán jellemzően az egy före eső GDP-ben meghatározott gazdasági növekedés általános célja nem utal a természeti környezet állapotára, amely legfeljebb az életminőséggel hozható kapcsolatba áttételeken keresztül. A regionális versenyképesség széles körben elfogadott piramis modelljében sem áll elötérben a természeti töke, hanem csak a sikerességi faktorok, a versenyképesség hosszú távú forrásai között szerepel a „környezet minősége” (environment) (Lengyel 2000; Gardiner-Martin-Tyler 2004,).

Összességében elmondható, hogy a rövid távú versenyképességnek nem szabad a gazdasági tevékenységet fenntarthatatlanná tevő egyensúlytalanságot létrehoznia. Ez a felismerés nyert teret az Európai Unió döntéshozói elött Göteborgban 2001-ben, amikor a lisszaboni deklarációt kiegészitették a fenntarthatóság elvárásával ( $E C$ 2001). A hosszú távú versenyképességnek megkerülhetetlen feltétele a fenntarthatóság, illetve annak egyik elemeként a gazdaság és társadalom számára nélkülözhetetlen szolgáltatásokat nyújtó természeti tőke.

\section{A természet szerepe a gazdasági folyamatban}

A természet a gazdaság és társadalom müködéséhez különböző termékeket és szolgáltatásokat nyújt, többféle funkcióval bír (Gustaffson 1998; Ekins et al 2003; Gonczlik 2004; MEA 2005). Ezen funkciók megragadására, leirására és rendszerezésére több, egymástól eltérỏ csoportosítást dolgoztak ki (1. táblázat).

E csoportosítások mindegyike megegyezik abban, hogy a természet a gazdasági rendszer és az emberi élet számára nélkülözhetetlen szolgáltatásokat (ökoszisztémaszolgáltatások) nyúitja a biodiverzitás ${ }^{4}$ által fenntartott ökológiai folyamatokon (ökoszisztéma-folyamatok) keresztül (Ekins et al 2003). Ezt a viszonyt úgy is meghatározhatjuk, hogy az ökoszisztéma-szolgáltatások pusztán (a biodiverzitás által fenntartott) ökoszisztéma-folyamatok eredményeképpen jöhetnek létre. Az öko- 
szisztéma-folyamatok meglétében, és így a természet által a társadalom és gazdaság számára nyújtott szolgáltatásokban tehát kulcsszerepe van a biodiverzitásnak.

\author{
1. TÁBLÁZAT
}

A természet funkciói

(Functions of the Nature)

\begin{tabular}{ll}
\hline \multicolumn{1}{c}{ Funkció } & \multicolumn{1}{c}{ Definició } \\
\hline Forrás funkciók & Képesség erőforrások biztosítására. \\
Elnyelö funkciók & Képesség a szennyezések semlegesíté- \\
& sére az ökoszisztémák megváltozása, \\
& sérülése nélkül. \\
Életet támogató funkciók & Képesség az ökoszisztémák egészsé- \\
& gének és múködésének fenntartására. \\
Egyéb emberi egészséggel és jólét- & Képesség az emberi egészség fenntar- \\
tel kapcsolatos funkciók & tására és az emberi jólét egyéb módon \\
& történó generálására. \\
\hline
\end{tabular}

Forrás: Ekins et al (2003) alapján.

A biodiverzitás és az ökoszisztéma-folyamatok egyre súlyosabb sérülésének következtében az ember ökoszisztéma-szolgáltatásokat veszélyeztetö bioszféraátalakitó tevékenysége (lényegében a társadalmi-gazdasági rendszer müködése) egyre inkább kardinális probléma ${ }^{5}$ a termelékenységre és így a regionális versenyképességre gyakorolt potenciális hatás következtében (Stern 2006).

Mivel a globális gazdasági rendszer lehetőséget nyújt a természetbỏl nyert materiális javak nagymértékü földrajzi transzferére, a mobil javak szállítására, így a természeti tôkének, mint termelési tényezőnek adott régióban való megléte első közelítésben nem feltétlenül tünik meghatározó versenyképességi tényezőnek. Ugyanakkor a fejlett országok gazdasági növekedését az ipari forradalom óta egyebek mellett a fejlődőktől történő természeti erőforrás transzfer, erőforrás elvonás teszi lehetôvé (Röpke 2005). Ennek bizonyítékaként többen (Andersson-Lindroth 2001; Giljum-Eisenmenger 2004; Schütz et al 2004) megállapítják, hogy az északi (fejlett) országok (régiók) délről (fejlődőktől) biokapacitást importálnak ${ }^{6}$. E transzferlehetőség következtében a természeti tőke adott régióban rendelkezésre álló menynyisége és annak milyensége addig, amíg az anyagi javak alapjait képező ökoszisztéma-folyamatok és a létfontosságú ökoszisztéma-szolgáltatások globálisan, illetve más régiókban rendelkezésre állnak, az importáló régiókban nem feltétlenül jelenik meg versenyképességi tényezöként. Ugyanakkor, ha az ökoszisztéma-folyamatok globálisan, azaz minden régiót érintően sérülnek, és a természeti tőke globális léptékben degradálódik, és létfontosságú ökoszisztéma-szolgáltatások (immár globális léptékben) elvesznek - mint ahogyan a bioszféra állapotával foglalkozó dokumentumok (UNDP et al 2000; WWF 2004; 2006; Stern 2006; IPCC 2007) szerint ez napjainkban történik -, akkor e transzferlehetöség (importlehetőség) is elvész. Min- 
denképpen aktuális tehát az ökoszisztéma-folyamatok és a létfontosságú ökoszisztéma-szolgáltatások gazdasági jelentőségének vizsgálata, hiszen az ökoszisztémafolyamatok megváltozása súlyos negatív gazdasági versenyképességi következményekkel járhat.

\section{Csökkenö termelékenység}

A bioszféra müködésének ember általi megváltoztatásával kapcsolatosan legalább három, a termelékenység csökkenésére ható probléma jelenik meg (Ehrlich-Wilson 1991):

1) a természet esztétikai minőségének leromlása;

2) a gazdasági lehetőségek beszúkülése és

3) a létfontosságú ökoszisztéma-szolgáltatások ${ }^{7}$ elvesztése.

E problémák azért jelentkeznek, mert a bioszféra ember általi megváltoztatása hat az ökoszisztéma-folyamatok minőségére. $\mathrm{E}$ folyamatok minőségének megváltozása a regionális versenyképesség szempontjából kulcsfontosságú, hiszen e folyamatok létezése nélkül a különböző ökoszisztéma-szolgáltatások sem mủködnek, így e változás nagymértékben beszükítheti a materiális javakkal kapcsolatos jövőbeni lehetőségeket, növeli az ezek elérhetőségével kapcsolatos bizonytalanságot - lévén, hogy a természeti folyamatok az emberi jólét, az emberi társadalmaknak nyújtott jószágok közvetlen vagy közvetett forrásai (Buday-Sántha 2004). Másrészról, bizonyos ökoszisztéma-folyamatok jelenlegi ismereteink szerint nagyobb léptékben gyakorlatilag sem egymással, sem emberi technológiával nem helyettesíthetők (Gustaffson 1998; UNDP et al 2000; Buday-Sántha 2002), illetve földrajzi értelemben nem transzferálhatók (importálhatók/exportálhatók).

A biodiverzitás ,pótlás nélküli” csökkenésének napjainkban megfigyelhető folyamata tehát olyan ökoszisztéma-folyamatok elvesztéséhez vezet, melynek következtében a mással nem helyettesithetö létfontosságú ökoszisztéma-szolgáltatások sérülnek $^{8}$ (Gustaffson 1998; UNDP et al 2000; Buday-Sántha 2002), amelyek a legtöbb materiális jószág alapját is képezik.

A bioszféra-átalakítási tevékenység hatásainak elemzése meglehetösen komplex feladat, manapság leginkább annak legakutabb és legsúlyosabb következményekkel járó szegmensén, a globális klímaváltozáson keresztül ragadják meg. A globális klímaváltozás ökológiai-társadalmi-gazdasági hatásaival foglalkozó jelentések közül kiemelkedik az International Panel on Climate Change legutóbbi jelentése (IPCC 2007), illetve a folyamatot a GDP-re gyakorolt hatás szempontjából elemző és számszerüsító Stern-jelentés (Stern 2006). E dokumentumok egyöntetüen leszögezik, hogy az éghajlatváltozás gazdasági következményei bizonyos térségek számára rövid távon akár még pozitívak is lehetnek, ugyanakkor minél nagyobb a változás mértéke, annál inkább felülmúlják a negatív hatások a pozitívakat. A konkrét gazdasági hatásokat felbecsülő Stern-jelentés szerint az éghajlatváltozás a Föld lakosságának alapvető életfeltételeit - vízhez való hozzájutás, élelmiszer-termelés, embe- 
rek egészsége, ill. a föld és a környezet használata - veszélyezteti (létfontosságú ökoszisztéma-szolgáltatások elvesztése). GDP-ben kifejezve a jelentés megállapítja, hogy a hatások és a lehetséges következmények teljes skáláját figyelembe vevő elemzések az egy före jutó fogyasztás globális átlagának mostantól az idők végezetéig tartó (azaz folyamatosan, évröl-évre jelentkező és soha nem csökkenő, esetleg növekvő) 5-20\%-os csökkenésével számolnak - a korrekt becslés ráadásul nagy valószínűséggel a tartomány felső részébe esik (gazdasági lehetöségek beszükülése).

\section{Az ökológiai változások termelékenységet csökkentő hatásának természete és térbelisége}

A termelékenységet közvetlenül befolyásoló ökoszisztéma-szolgáltatások közvetlen sérülésén túlmenően a biodiverzitás és az ökoszisztéma-folyamatok megváltozása közvetve is eredményezheti a termelékenység mérséklödését. A biodiverzitás csökkenésével ugyanis megváltozik az ökológiai rendszer, és így csökken annak alkalmazkodási potenciálja (Tilman 2000). Másrészről, megváltoznak a fajok ökoszisztémával kapcsolatos funkcionális jellemzői, és így az ökoszisztéma folyamatai. Azaz a biodiverzitás külső körülmények változása következtében létrejövő megváltozása mintegy pozitív visszacsatolási hurokként (Chapin et al 2000) változást indukál az ökológiai rendszerek biotikus és abiotikus tényezőiben ${ }^{9}$ (Gonczlik 2004), ami pedig az alkalmazkodási folyamat megnehezítése által újabb biodiverzitáscsökkenést eredményezhet. Így tehát a biodiverzitást csökkentö hatások nem egyszerüen összeadódnak, hanem szinergikus hatásúak, ami tovább súlyosbíthatja a biodiverzitás csökkenéséből fenyegetö veszélyeket (Bajomi 2004), és a rendszer mủködésében nagyfokú tehetetlenséget eredményez. E tehetetlenségre és az alkalmazkodási lehetőségek beszűkülésére utalnak a Stern-jelentés (2006) azon megállapításai, amelyek értelmében az egy före jutó fogyasztás globális átlagának 5-20\%-os csökkenése az idök végezetéig tartó tendencia, ill. hogy a megelóző (hatásokat mérséklő) és alkalmazkodást segítő intézkedések megtétele ennél nagyságrendekkel olcsóbb. Nyilvánvaló tehát, hogy a gazdasági rendszer müködésének jelenlegi folyamatai magának a rendszernek a jövőbeni termelékenységét ássák alá.

Az ökológiai változások területi aspektusaihoz kapcsolódik az ökológiai rendszerek interdependens mivolta. Az ökológiai irodalom szerint bármely hatás az egész ökoszisztémában - és végül is így az egész bioszférában - átadódik, azaz a rendszer minden elemére közvetlenül vagy közvetve hat (Vida 2001). Így a kapcsolatok meglehetősen szövevényesek, az ökológiai rendszer elemei közt bonyolult interdependenciák érvényesülnek (Norgaard-Bode 1998), adott esetben, globális léptékben is - lásd az élővilág (elsősorban a növényzet) megváltozásának már említett klimatikus hatásait. A globális környezeti problémák elnevezés pontosan arra utal: hogy a környezeti problémák tekintetében a (nemzet-, régió-) határok fogalma többé nem értelmezhetö (Buday-Sántha 2002). Az egyes területek gazdasági tevékenysége által előidézett problémák a többi területet is érintik (pl. savas esők, ég- 
hajlatváltozás, ózonréteg elvékonyodása), és a más területek által előidézett problémák hatásai alól adott területi egység nem vonhatja ki magát. ${ }^{10}$

Ezen interdependenciákból fakadóan a külföldi biokapacitás nettó használata ${ }^{11}$ - a biomassza importja és szennyezés exportja (a szennyezés-elnyelő képesség importja) - azt eredményezheti, hogy adott ország más országok biokapacitásától függ, amennyiben fogyasztási szintjét fenn szeretné tartani (Andersson-Lindroth 2001). Ennek következtében a két ország kereskedelme kölcsönösen fenntarthatatlanná válhat (mutually unsustainable exchange), amennyiben a biokapacitás-exportáló ország saját természeti tökéje csökken - ez ugyanis nem csupán saját, hanem a töle addig importálni képes ország fogyasztási lehetőségeit is csökkenti. A (kevésbé fejlett) déli régiók természeti tőkéjének erodálódása (a fejlett) északon is megjelenik fenntarthatósági problémaként. Ráadásul a fogyasztáscsökkentést kiváltó hatás észak-dél viszonylatban a globális interdependenciák megléte miatt közvetett módon is bekövetkezhet - azaz azáltal, hogy a biokapacitást exportáló (déli) ország természeti tőkéjének erodálódása az interdependenciák következtében az importáló ország természeti tökéjének minőségére is negatívan hat ${ }^{12}$.

A globális léptékủ interdependenciák meglétén túlmenően a bioszféra ember általi megváltoztatásának természetét, valamint a pusztítás megszüntetésének leghatékonyabb eszközeit és lépéseit nagyfokú bizonytalanság övezi (Novacek-Cleland 2001; Gowdy 2004). Az emberi tevékenység ökoszisztémákra gyakorolt hatásának jellemzésekor a tiszta bizonytalanság is fellép, azaz bizonyos döntési helyzetekben sem az egyes alternativák következményeit, sem a következményekhez rendelhetó bekövetkezési valószínüségeket nem ismerjük. Így például nem lehet tudományos bizonyossággal meghatározni a kritikus természeti tőke ${ }^{13}$ (Critical Natural Capital, CNC) szintjét, minimumát, formáját (Ekins et al 2003; Buday-Sántha 2004). Az UNDP találó megfogalmazása szerint ökoszisztémákkal kapcsolatos tudásunk ugyan sokat gyarapodott, de semmiképpen sem képes lépést tartani ökoszisztémaátalakító képességünkkel (UNDP et al 2000). Így a fenyegetések régiónkénti relatív nagyságrendjével kapcsolatosan alapvetô információk sem állnak sokszor rendelkezésre (Woodruff 2001).

E bizonytalanság és az interdependenciák a regionális termelékenység szempontjából azt eredményezik, hogy a változás mértéke mellett annak területi hatásait sem jelezhetjük pontosan elöre. Ennek értelmében azon túl, hogy e bizonytalanság a társadalmi alkalmazkodást megnehezíti és költségesebbé teszi (Chapin et al 2000), nehéz például azt megmondani, hogy egyes globális közjavak (stabil klíma, trópusi esőerdők) megváltozása adott régiók termelékenységét pontosan hogyan befolyásolhatja.

A fentiek összegzéseként tehát elmondhatjuk, hogy a természeti töke egy speciális jellemzőkkel rendelkezö tőketípus, amelynek bizonyos elemei (precízebben bizonyos ökoszisztéma-szolgáltatások) jelen tudásunk alapján mindenféle emberi szükséglet-kielégítési cselekvés alapját képezik és semmi mással nem helyettesíthetök. Megítélésünk szerint tehát e tőketípus regionális versenyképességben (és egyáltalán bármilyen gazdasági folyamatban) betöltött szerepének (szélesebb értelemben a gazdaság-természeti tőke, illetve. regionális versenyképesség-természeti tőke relá- 
ció) elemzése nyilvánvalóan egy nagyon lényeges kutatási kérdés. A következő fejezetben öt közgazdaságtani irányzat elméleti megközelítését vizsgáljuk meg abból a szempontból, hogy a természeti tőke és a regionális versenyképesség kapcsolata megjelenik-e ezekben, és ha igen, akkor ez milyen módon.

\section{A regionális versenyképesség és a természeti töke értelmezése}

A továbbiakban először azt vizsgáljuk, hogy van-e kapcsolat az alapvetö közgazdaságtani irányzatokban az ökológiai fenntarthatóság és a regionális versenyképesség, ehhez kapcsolódva a termelékenység egymástól látszólag külön életet élő fogalmai közt. Elemezzük továbbá, hogy amennyiben e kapcsolat megjelenik, akkor az erre vonatkozó közgazdaságtani vizsgálatok milyen mértékben képesek integrálni a természeti tőkével, illetve annak gazdasági folyamatban betöltött szerepével kapcsolatos jelenlegi ökológiai ismereteinket.

A különböző közgazdaságtani irányzatok eltérő elméleti háttérfeltételekből kiindulva más-más következtetéseket fogalmaznak meg a regionális versenyképesség meghatározó tényezőivel és a természeti tőke gazdasági szerepével kapcsolatosan (Martin et al 2003; Kitson et al 2004, Rechnitzer-Smahó 2005; Lukovics 2007). Általunk a következőkben e szempontból vizsgált közgazdaságtani irányzatok a következők:

- neoklasszikus közgazdaságtan,

- fejlődés gazdaságtana,

- evolucionista közgazdaságtan,

- új intézményi közgazdaságtan és

- a verseny új közgazdaságtana (2. táblázat).

A neoklasszikus elmélet keretében a növekedési modell alapfeltevéseiböl (ezek a tökéletes informáltság, az állandó skálahozadék, a hosszú távon érvényesülő egyensúlyi helyzet, a teljes tényezőmobilitás és a tökéletes verseny) és eszközrendszeréböl kiindulva a területi verseny és így a regionális versenyképesség témaköre nem tárgyalható (Török 1999; Krugman-Obstfeld 2003). Ennek oka, hogy a neoklasszikus elmélet értelmében a térbeli egyensúly önmagától, spontán piaci folyamatok eredményeképpen kialakul, emiatt nincs értelme területi versenyről beszélni. Továbbá „a versenyidegen jelenségek (legyen az állami beavatkozás vagy bármely versenykorlátozó megnyilvánulás) hatékonyság-veszteséggel járnak" (Lukovics 2007, 17).

A neoklasszikus elmélet megalkotóinak tekinthető szerzők (még) foglalkoztak a természeti töke gazdaságban betöltött szerepével. Jevons nagy figyelmet szentelt a szén gazdaságban, gazdasági növekedésben betöltött szerepének (a szénkészletek kimerülésének Nagy-Britannia gazdaságára gyakorolt hatásával kapcsolatosan meglehetősen pesszimista volt) (Spash 1999; Bekker 2000). Valamint az ö nevéhez füzödik a manapság újrafelfedezett Jevons-paradoxon (Alcott 2005), amely az ökohatékonyság ( WWF 2006) természetmegörzésben betöltött szerepének jelentöségét kérdőjelezi meg. A későbbiekben a neoklasszikus irányzat mérvadó szerzői - 
Málovics György - Ván Hajnalka :

Az ökológiai fenntarthatóság és a regionális versenyképesség összefüggései.

Tér és Társadalom 22. évf. 2008/2. 21-40. p.

TÉT XXII. évf. 2008 — 2

Az ökológiai fenntarthatóság és a ...

legyen szó növekedéselméletekről, vagy a nemzetközi kereskedelmet magyarázó Heckscher-Ohlin modellról - a természeti tőke termelési folyamatban betöltött szerepét nem vizsgálják, a termelési tényezőket a munkával és az ember alkotta (mesterséges) tőkével azonosítják (Ekins et al 2003; Gardiner-Martin-Tyler 2004).

\section{TÁBLÁZAT}

A természeti töke regionális versenyképességi aspektusai egyes közgazdaságtani irányzatokban

(The Regional Competitiveness Aspects of Natural Capital in Certain Economic Tendencies)

\begin{tabular}{ccc}
\hline $\begin{array}{c}\text { Közgazdaságtani } \\
\text { irányzatok }\end{array}$ & $\begin{array}{c}\text { A természeti tóke } \\
\text { megjelenése }\end{array}$ & $\begin{array}{c}\text { A regionális versenyképesség } \\
\text { befolyásoló tényezöi }\end{array}$
\end{tabular}

Neoklasszikus növekedési modellek

Fejlödés gazdaságtana

Evolucionista közgazdaságtan

Új intézményi közgazdaságtan

$A$ verseny új közgazdaságtana
A gyenge fenntarthatóság elmélete, a természeti tőke redukcionista, jelenlegi ökológiai tudásunk alapján nem tartható megközelítése.

A szigonúbb környezeti szabályozás hátrány a nemzetközi versenyben.

Közvetve: társadalmi egyenlötlenségek, szegénység problémája, jólét többdimenziós mérése.

Technológiai változás folyamata: útfüggőség, bezáródás, technológiai rezsimek.

Környezeti konfliktus, természeti erőforrások, tranzakciós költségek, technológiai változások és intézmények, kollektív cselekvés, tulajdonjogok és szegénység.

Környezeti politika és nemzetközi versenyképesség.
A regionális versenyképesség témaköre ezen elmélet korlátai között nem tárgyalható.

Központi régiók termelékenységi előnye.

A jelenben megfigyelhetö események dinamikus folyamat eredményei, a vállalati és ipari struktúra és a gazdasági intézmények együttes fejlódése, helyi feltételek, helyi történelmi háttér, térségek innovációt generáló képességei, térbeli koncentráció szerepe. Intézmények, tulajdonjogok, tranzakciók, tranzakciós költségek térbelisége.

Makroökonómiai szempontok helyett egyre inkább a mikrogazdasági alapok, innovációs készségek, kapacitás fejlesztése, klaszterekben, hálózatokban, valamint kis- és középvállalkozásokban való gondolkodás, a gazdaság-és társadalompolitikai célok integrálása.

Forrás: Saját szerkesztés. 
A környezeti probléma felismerése következtében az 1960-as évektől a természeti tőke bekerült a termelési függvény inputtényezöi közé. A természeti tỏke neoklaszszikus termelési függvénybe történő integrálásából keletkezett a gyenge fenntarthatóság elmélete ${ }^{14}$, amely azonban oly mértékben valóságidegen feltételezéseket alkalmaz e tőketípusra vonatkozóan ${ }^{15}$, hogy sokak szerint nem magyarázza a természeti tőke termelési folyamatban betöltött szerepét, hanem azt gyakorlatilag (a formai figyelembevétel mellett) teljes mértékben figyelmen kívül hagyja (Gutés 1996; Ekins et al 2003). Megítélésünk szerint ez magyarázhatja, hogy a neoklasszikus közgazdaságtanban gyakorlatilag teljes mértékben (Solow 1997; Stiglitz 1997), míg a neoklasszikus alapokon nyugvó környezet-gazdaságtani mikroökonómiai elméletben a természeti környezet védelmének megközelítése első sorban - de nem pusztán az externáliák internalizálásához és a piaci/közgazdasági környezetvédelmi eszközökhöz kapcsolódik (Turner 1989; Kerekes-Szlávik 2001). Ennek ugyanakkor nagyon komoly elméleti és gyakorlati korlátai ${ }^{16}$ vannak (Costanza et al 1997; Pimm 1997; Daily et al 2000). Azaz a neoklasszikus közgazdaságtan egy egységes, zárt logikájú fenntarthatósági elmélettel rendelkezik (melynek kulcsfogalmai a helyettesítés és az internalizálás), amelynek azonban gyakorlati jelentősége azáltal, hogy nem integrálja szervesen a természeti tőkével kapcsolatos ismereteinket - sőt, esetenként azzal homlokegyenest ellenkező feltételezésekböl indul ki-, megkérdőjelezhető.

A fejlödés gazdaságtana, mint önálló diszciplína az elmaradott országok fejlődési problémakörére vonatkozó tudományterületként jelent meg (Szentes 2003). Az irányzatnál idővel folyamatosan elötérbe kerültek a külső, nemzetközi tényezők és hatások (a világgazdaságtan egyenlőtlen viszonyai és különbségeket növelő hatásai, a fejlett országok gazdaságának strukturális függése) szerepét hangsúlyozó megközelítések. Az irányzat értelmében a központi régiók kezdeti termelékenységi elönyeik segítségével fenntartják vezető helyzetüket a kevésbé termelékeny periférikus régiókhoz képest, a régiók termelékenységbeli felzárkózása egy lassú folyamat, a politikáknak figyelembe kell venniük adott régió fejlettségi állapotát (Martin 2003). Az elmélet egyfajta regionális gazdaságtani „,megfelelöje” Myrdal kumulatív fejlödési modellje (Lengyel-Rechnitzer 2004).

Ugyan e megközelitésre hatott az elsősorban a Római Klub dokumentumainak következtében egyre nyilvánvalóbbá váló ökológiai problémakör (Szentes 2003), de a természeti tőke ezen elméletnek sem képezi szerves részét. Az irányzat sokkal inkább a társadalmi egyenlőtlenségekre, a szegénység problematikájára, nem pedig az ökológiai problémákra összpontosít (Thorbecke 2006). Mégis, ez az elmélet a regionális versenyképesség és a természeti környezet összekapcsolása szempontjából mindenképpen jelentős mondanivalóval bír, melynek oka kettős. Egyrészt a fenntarthatósági szakirodalom egyik irányzatának értelmében a jövedelemegyenlötlenségek problémája nem választható el az ökológiai problémakörtöl. Egy globális szinten is egyenlőbb jövedelemelosztás (Daily et al 1995; Daily-Ehrlich 1996), a fejlett országokban a fogyasztás csökkentése (Röpke 1999; Brown-Cameron 2000), a „kényelmes” életmód feláldozása" (Csutora-Kerekes 2004) és a fejlödő világbeli nyomor felszámolása az ökológiai krízis megszüntetésének alapfeltételét képezik. 
Másrészt, az irányzat az ökológiai szempontból potenciálisan meglehetősen káros mutatónak tekinthető GDP/GNP (Szlávik 2006) (egy före eső) puszta növekedését nem tekinti egyértelmüen fejlödésnek, hanem a többdimenziós mérések szükségessége mellett érvel, ilyen mutató lehet az ENSZ HDI-je (Emberi Fejlödés Indexe Human Development Index) (UNDP 1990). Ehhez kapcsolódó fontos elmélet az ún. alapvetó igények (basic needs) koncepciója (Streeten 1981), valamint az ezen alapuló, a szegénység mérésére kifejlesztett - és így a jólét, a fejlődés megragadásának alapjául is szolgálni képes - többdimenziós módszerek (Bourguignon-Chakravarty 2003). Azaz az irányzatban a természeti tőke koncepciója nem jelenik meg, mégis bizonyos szempontból releváns mondanivalóval bír a fenntarthatósággal és annak regionális versenyképességhez való viszonyával kapcsolatosan.

$\mathrm{Az}$ evolucionista közgazdaságtan - ugyan első átfogó eredményeképpen egy mikroökonómiai megalapozású makromodellt dolgozott ki - legszéleskörübb alkalmazása az innovációkutatások területén figyelhetö meg (Bajmócy 2007). Az irányzat központi fogalmai közé tartoznak a heterogenitás, a komplexitás és a bizonytalanság (Martin 2003). Az evolúciós elmélet sem nem determinisztikus, sem nem véletlenszerü, a jelenben megfigyelhető eredményeket a múltbeli állapotból kiindulva dinamikus folyamat eredményeként értelmezi (Dosi-Nelson 1994). Ezen eredmények nagymértékben a "gazdasági evolúció" részei, a helyi feltételek és történelmi háttér által befolyásoltak. A hosszú távú regionális versenyképesség így a térségek újdonságot, innovációt generáló képességének függvénye. Ebben fontos a térbeli koncentráció szerepe. A folyamatosan létrejövő új variációkat a verseny és más intézmények kiszelektálják (Lukovics 2007).

Az irányzatnak - potenciálisan - a természeti tóke és a gazdaság összefüggéseinek vizsgálatában is komoly szerepe lehetne, ugyanakkor egyelőre „meglepő” mértékben elhanyagolja a természet gazdasági folyamatban betöltött szerepének vizsgálatát (van den Bergh 2007). Pedig az irányzat egyik alapvetô vizsgálati területe $a$ technológiai változás folyamata. Az ezzel kapcsolatos „kulcsfogalmak”, „kulcsmegállapítások", mint a korlátozott racionalitás, a technológiák használatának pozitív visszacsatolásai és negatív extern hatásai, a technológiai változások növekvő hozadéka, az útfüggőség, a bezáródás (van den Bergh 2003; 2007; Bajmócy 2007) és a technológiai rezsimek ${ }^{17}$ (Kemp et al 1998; Pataki 2000) a természeti tóke és gazdasági rendszer (és regionális versenyképesség) kapcsolatáról igencsak lényeges mondanivalóval bírnak (bírhatnának).

Az új intézményi közgazdaságtan - már önmagában is interdiszciplináris - értelmezése szerint a piac csak egy változata azon társadalmi mechanizmusoknak, ahol az egyén magatartása kifejeződik. Így vizsgálatának fókuszába az kerül, hogy az önérdekkövető egyének hogyan fejlesztik ki intézményeiket (szokásaikat, konvencióikat, szabályaikat stb.) (Szabó 2003). Az irányzat kulcsterületeinek a tranzakciós költségek közgazdaságtana (Coase, Williamson) és a tulajdonjogok gazdaságtana (Coase, Alchian) tekinthetők (Richter 2005). A regionális versenyképesség meghatározói a tágan értelmezett intézményi környezet és az ezzel kapcsolatba hozható 
Az ökológiai fenntarthatóság és a regionális versenyképesség összefüggései.

Tér és Társadalom 22. évf. 2008/2. 21-40. p.

keresési és információs, kommunikációs, koordinációs, valamint alku-és döntési-, továbbá ellenörzési és kikényszerítési költségek (Martin 2003; Lukovics 2007).

Bár az irányzat homlokterében itt sem a gazdaság-természet viszony áll (Paavola-Adger 2006; Paavola 2007) - sokkal inkább a gazdasági szervezetek, közösségi választások, gazdasági fejlödés és a gazdaságtörténet -, mégis fontos mondanivalóval bír a fenntarthatóság szempontjából is. Az elmélet természeti környezettel kapcsolatos vizsgálódásainak fỏ irányát a helyi közös tulajdonnal kapcsolatos kutatások (például a hagyományos közös tulajdonnal kapcsolatos intézmények) és a nemzetközi környezeti kormányzás képezik. Az irányzat környezeti szempontból lényeges mondanivalója egyrészt a környezettel kapcsolatos pozitiv tranzakciós költségek felismerése. A tranzakciós költségek környezeti kormányzással kapcsolatos egyik legfontosabb következménye, hogy az irányítási intézmények nem tervezhetők meg ex ante tökéletesen. Továbbá, a természeti erőforrások és használóik jellemzői által befolyásolt tranzakciós költségek meghatározzák a környezeti kormányzás hatásosságát és kimeneteit, illetve az intézményi konstrukció is hat a tranzakciós költségekre.

A tranzakciós költségeken túlmenően az irányzat környezeti szempontból lényeges másik fö eredménye, hogy az externáliák szük koncepciója helyett az interdependenciák - amikor is egy gazdasági szereplő választása befolyásolja más(ok) választását - koncepcióján keresztül közelíti meg a környezeti problémát. $\mathrm{Az}$ interdependens ügynökök nem tudják egyszerre realizálni inkompatibilis érdekeiket egy szükös természeti erőforrásokkal jellemezhető környezetben, ez pedig környezeti konfliktushoz vezet. A konfliktusok feloldásához a kezdeti adottságok (initial endowments) megerősítése vagy (újra)definiálása szükséges a tulajdonjogok meghatározása vagy egyéb jogokat létrehozó kormányzati intézmények alapítása, megerősítése, esetleg megváltoztatása által. E folyamatnak allokációs és disztributív következményei egyaránt vannak, és az allokációs hatékonyság eléréséröl csak a kezdeti adottságok meghatározása után beszélhetünk. Ennek következtében a disztributív következmények és az irányítási kimenetek a környezeti kormányzással kapcsolatos kollektív választások legfontosabb dimenziói. Így Paavola (2005) szerint az új intézményi közgazdaságtan szempontjából a környezeti probléma allokációs helyett sokkal inkább (folyamat- és disztributív) igazságossági probléma.

Az ủj intézményi közgazdaságtanban ${ }^{18}$ a fentiek függvényében megjelennek a természeti környezettel kapcsolatos kutatások: a fenntartható növekedés és az intézmények viszonya, a természeti erőforrások kezelése és az intézmények kapcsolata ${ }^{19}$, a tranzakciós költségek és természeti erőforrások viszonya, a természeti eröforrások menedzsmentjének politikai vonatkozásai, a környezeti szabályozás és intézmények viszonya, a kollektív cselekvés és tulajdonjogok szerepe a szegénység csökkentésében ${ }^{20}$, egyenlötlenségek, a segélyezés, igazságosság és intézmények kapcsolata $^{21}$, valamint a technológiai változások és intézmények viszonya ${ }^{22}$. Itt is megfigyelhetỏ tehát az, ami a neoklasszikus irányzaton kívül a többi esetében: az irảnyzatnak nincs egységes fenntarthatóság-versenyképességi elmélete, ám potenciálisan lényeges mondanivalója e kapcsolatról igen sokrétủ. 
A regionális versenyképesség egyik koherens áramlata Michael Porter nevéhez kötödik (Porter 1998). A verseny új közgazdaságtanának egyre szélesebb körben elfogadott nézeteinek értelmében a fejlödést napjainkban a makroökonómiai szempontok helyett egyre inkább a mikroökonómiai alapok határozzák meg (Lengyel 2003). A gazdaságpolitika a hagyományos beruházás-ösztönzés, infrastruktúrafejlesztés felól egyre inkább az innovációs készségeket, kapacitást fejleszti, és ágazatok, nagyvállalatok helyett klaszterekben, hálózatokban, valamint kis- és középvállalkozásokban gondolkodik. A pusztán gazdasági szemlélet helyett integrálja a gazdaság- és társadalompolitikai célokat, amelyeket egymástól elkülönülten kezelni nem lehet. Domináns területi egységgé a nemzeti helyett a regionális, illetve lokális szint válik, és a vállalati versenyelónyök jelentós része a helyi környezetból ered.

Porter foglalkozik kifejezetten a környezeti célok és a versenyképesség kapcsolatával is - iparági és vállalati szinten egyaránt (Porter-van der Linde 1995). Meglátása szerint a szigorúbb környezeti szabályozás a versenyképességet növelö irányba hat, mivel az a környezeti javak (termelési alapanyagok és szennyezésbefogadó közeg) esetében szükíti a tényezőellátottságot, és ezáltal innovációra sarkall (BodaPataki 1995). E megállapítása kapcsán Porter hajlamos egyfajta nyertes-nyertes (win-win) pozícióról, azaz a társadalom (esetünkben a természeti környezet) és a vállalkozás (gazdaság) számára egyaránt pozitív helyzetről írni (Porter-Kramer 2006). Ugyanakkor elméletének komoly korlátja ${ }^{23}$, hogy nem definiálja mit is ért környezetügy, környezetvédelem alatt. Mint ahogyan az direkt módon is megjelenik (Porter-van der Linde 1995), nem vizsgálja a környezeti szabályozás (szakirodalom által nem egyértelmúen megítélt) társadalmi hasznossági vonatkozásait - azaz, hogy vajon valóban hozzájárul-e a környezetpolitika a természeti környezet megörzéséhez és így a társadalom jólétének nơveléséhez. Helyesebb, ha azt írjuk, hogy Porter a környezeti politika (ami korántsem azonos a természeti tơke megörzésével) és a versenyképesség viszonyát vizsgálja, és elméletének mondanivalója ennél fogva a természeti tőke és a versenyképesség viszonyáról meglehetösen korlátozott.

A közgazdaságtani irányzatok fenti áttekintése alapján kijelenthetö (lásd 2. táblázat), hogy a neoklasszikus közgazdaságtan az egyetlen a vizsgált irányzatok közül, amely egy egységes ,irányzati” környezet-gazdaság elmélettel rendelkezik. Ugyanakkor ezen elmélet fogalomrendszerében a regionális versenyképesség témaköre nem értelmezhető, hiszen mindenféle "piacidegen” beavatkozás hatékonyságvesztést eredményez. Továbbá, ezen irányzat „természetképe” jelenlegi ökológiai ismereteink tükrében - mint ahogyan azt már említettük - nehezen tartható, mivel az nem integrálja a természeti tőke ma ismert jellemzöit. Talán nem túlzás, ha ezen okokból kifolyólag ezen elmélet témánk szempontjából igencsak redukcionistának tekinthetỏ.

A neoklasszikus közgazdaságtan komoly „birálataként” is felfogható többi, általunk bemutatott közgazdaságtani irányzat megítélésünk szerint az empirikus igazolhatóság szempontjából lényegesen védhetőbb feltételezésekkel él, a valóságos folyamatokat jobban közelítő állításokat fogalmaz meg mind a regionális versenyképességgel, mind pedig a természeti tőkével kapcsolatosan. Ezen irányzatok mondanivalója komoly kihívást jelent a fỏáram (neoklasszikus közgazdaságtan) számára, 
és lényeges mondanivalóval rendelkeznek a regionális versenyképesség és a természeti töke szempontjából. Az irányzatok regionális versenyképességgel kapcsolatos mondanivalója ráadásul többször is - egymást kiegészítően -, egymással ,párhuzamos irányba mutat". A fejlődés gazdaságtanának függőségelmélete (és a kumulatív fejlődés), az evolucionista közgazdaságtan gazdasági evolúciót hangsúlyozó, helyi kontextus-függőséget kiemelő tézisei és az ủj intézményi közgazdaságtan intézményi környezetet vizsgáló irányzata egyaránt az univerzális megállapítások, a „mindenhol alkalmazható recept-típusú” megközelitések és a (neoklasszikus-típusú) túlzott redukcionizmus korlátaira és veszélyeire hívják fel a figyelmet. Hasonló üzenete van ezen irányzatok ${ }^{24}$ természeti tőkét érintő mondanivalójának (többdimenziós mérések szükségessége, technológiai rezsimek, tranzakciós költségek és környezeti konfliktusok) is.

A fenti okoknál fogva a természeti környezet és a gazdasági tevékenység (és így a regionális versenyképesség) viszonyával kapcsolatosan ezen irányzatok potenciálisan igen jelentős, egymást kiegészítő, és a neoklasszikus közgazdaságtanit erőteljesen megkérdôjelező mondanivalóval bírhatnak. Másfelől viszont a vizsgált elméleti megközelítések esetében a természeti tőke vizsgálata jellemzően nem áll az ágazat homlokterében, azaz nem tekinthetö „fơ” vizsgálódási területnek. Annál inkább a versenyképesség (termelékenység, gazdasági növekedés). Adott irányzatokon belül komoly „környezeti” kutatásokkal is találkozunk, de azzal már végképp nem, hogy mindezt a (regionális) versenyképességgel összefüggésbe hoznák. Azaz még amennyiben adott irányzat mind a (regionális) versenyképesség, mind pedig a természet szempontjából lényeges mondanivalóval rendelkezik, e két terület összekapcsolása nemigen történik meg - azaz a versenyképesség és a fenntarthatóság paradigmái „külön életet élnek”.

\section{Összegzés}

A természeti töke termelékenységbeli szerepének és öt közgazdaságtani irányzat természeti tőkével és regionális versenyképességgel kapcsolatos elméleti mondanivalójának áttekintése után kijelenthetỏ:

1) A természeti tőke gazdasági folyamatban betöltött kardinális szerepéhez viszonyítva - ahhoz, hogy az ökoszisztéma-folyamatok mindenféle emberi szükséglet-kielégitési képesség alapját képezik és mással nem helyettesíthetők - e tőketípus gazdasági szempontú elemzése a vizsgált irányzatokban viszonylagosan elhanyagolt.

2) Amennyiben e töketípus tárgyalására mégis sor kerül, akkor a természeti tőkével kapcsolatos aktuális tudásunk, a természeti tőke ma ismert jellemzőinek egyes irányzatokba történő integrálása jellemzően messze van attól, hogy azt teljes körünek nevezhessük.

3) Továbbá a vizsgált irányzatok mégis igen jelentős, gyakran egymást kiegészitő és erősítő, a neoklasszikus közgazdaságtani megközelités redukcionista mivol- 
tának létjogosultságát megkérdőjelező mondanivalóval rendelkeznek a természeti tőkéről és a regionális versenyképességről egyaránt.

4) Végül a - neoklasszikus közgazdaságtan kivételével - a természeti tőke és a regionális versenyképesség (termelékenység, növekedés) az irányzatokon belül jellemzően külön életet él.

Fenti okokból kifolyólag a regionális versenyképesség és a természeti tőke összefüggései mindenképpen alaposabb vizsgálatra szorulnak. Lényeges lenne kapcsolatot teremteni az ökoszisztéma-szolgáltatások és a fenntarthatóság, valamint a regionális versenyképesség jelenleg egymástól szinte tökéletesen „külön életet élő” fogalomrendszerei közt. E kapcsolat megteremtéséhez eszközül szolgálhat az ESDP (1999) hármas célrendszerében meglévő hatékonysági és fenntarthatósági elkülönülés „oldása” - utóbbi ugyanis föleg a méltányossági dimenzióhoz kapcsolódóan jelenik meg.

\section{Jegyzetek}

${ }^{1}$ Természetesen a Bruntland-jelentés és a közvélemény „fenntarthatóság-érzékenysége” nem elözmény nélküli, elég csak Carson (1962) vagy Meadows et al (1972) müveire gondolnunk.

2 Azzal, hogy a jellemzően egy fỏre eső GDP-ben mért gazdasági tevékenység a környezeti és jóléti közgazdászok szerint mennyiben alkalmas (illetve inkább alkalmatlan) a jólét mérésére (Sen 2003; Szlávik 2006), jelen tanulmányban nem foglalkozunk.

${ }^{3}$ A természeti tőkén keresztül igyekszünk megragadni az ökológiai fenntarthatóság koncepcióját.

${ }^{4}$ Ugyan a különbözö ökoszisztéma-szolgáltatások meglétéhez a biodiverzitás eltérő mértéke szükséges, ezt a mértéket - az ökoszisztémák később még részletezésre kerülő tulajdonságaiból fakadóan - elöre meghatározni egyelöre nem tudjuk.

${ }^{5}$ A természet gazdasági folyamatban betöltött szerepének vizsgálatakor sokszor párhuzamosan használják a természeti tőke, természeti erőforrások, természet és élő természet kifejezéseket. Buday-Sántha $(2004,13)$ szerint „A természeti tőke a ma alkalmazott fogalmi rendszer szerint a természeti eröforrásoknak, illetve a kömyezeti vagyonnak (nap, víz, levegö, ökoszisztémák) az a készlete, amely most és a jövöben az emberiségnek értékes javakat tud szolgáltatni." Dolgozatunkban e definícióval összhangban a természeti tỏke kifejezés alatt azon tỏkeállományt értjük, amely a gazdasági rendszer és emberi élet számára különbözö szolgáltatásokat nyújt. A különféle ökoszisztéma-szolgáltatásokat nyúitó természeti tóke adott szintjét tehát a (különbözö, de nem ismert mértékü) biodiverzitás által fenntartott ökoszisztéma-folyamatok garantálják.

${ }^{6}$ Az ilyen típusú mérések mindössze néhány évtizedes múltra tekintenek vissza.

${ }^{7}$ Létfontosságú ökoszisztéma-szolgáltatások (Ehrlich-Wilson 1991), életet támogató funkciók (lifesupport functions) (Ekins et al 2003) vagy fiziológiai szïkségletekkel kapesolatos szolgáltatások (fiziológiai szolgáltatások) (Gonczlik 2004) alatt a természet azon szolgáltatásait értjük, amelyek „létfenntartó funkciót töltenek be, az ember fiziológiai szükségleteit elégítik ki, vagyis lehetôvé teszik és fenntartják az életünkhöz nélkülözhetetlen körülményeket." (Gonczlik 2004, 20) E szolgáltatások - különbözö névvel illetve - az összes, a természeti tőke szolgáltatásaival kapcsolatos dokumentumban megjelennek, ezeket a továbbiakban egymás szinonimáiként használjuk.

${ }^{8}$ Ilyenek az ózonréteg által az ibolyántúli sugárzás kiszürése (Sántha 1996); a vizek mentesítése az abba bekerülő anyagoktól, illetve az emberi egészségre ártalmas, a tảplálékláncba kuilönben beépüló nehézfẻmek növények számára felvehetetlen formába történő hozása (Gonczlik 2004); a talaj - a szárazföldi élet feltételeit komplex módon garantálni képes egyetlen rendszer - fenntartása és létrehozása (Ehrlich-Wilson 1991; Sántha 1996), illetve képzödésének felgyorsítása a kỏzetek mállásának ezerszeresére-tízezerszeresére történő felgyorsítása által (Schwartzman-Volk 1989); a napenergia befogása és továbbadása a táplálékláncban (Gonczlik 2004); a nitrogén megkötése (növények által felvehetö formába történő változtatása) (Sárvári 1979); a beporzás (Nabhan-Buchmann 1997); és a növényi kár- 
tevök kontrollja (Ehrlich-Wilson 1991; Naylor-Ehrlich 1997). E felsorolásból látható, hogy a fiziológiai szolgáltatások egyben ökoszisztéma-folyamatok is. A lehatárolás tehát nem éles, inkább azt mondhatnánk, hogy az emberi türöképességet közvetlenül érintő ökoszisztéma-folyamatokat nevezzük létfontosságú ökoszisztéma-szolgáltatásoknak (l. még Chapin et al [2000] ökoszisztéma-szolgáltatás definícióját).

${ }^{9}$ E hatásokra szemléletes példa az élővilág éghajlatot befolyásoló hatása (Ehrlich Wilson 1991), amely mind lokális, regionális, mind pedig globális szinten jelentkezik. E folyamat lényege, hogy az élóvilág az atmoszféra és bioszféra közti anyag- és energiaáramláson keresztül befolyásolja, szabályozza a klímát (többek közt a hőmérsékleti minimumot és maximumot és a csapadékmennyiséget). Globális léptékben a bioszféra jelentôs mértékben hozzájárul bizonyos üvegházgázok légkő̉ri mennyiségének alakulásához, továbbá a növényzet jelentősen befolyásolja a földfelszín éghajlat kialakitásában meghatározó jellemzőit, mint pl. az albedót (a földfelszín fényvisszaverỏ képességét), az érdességet és az evapotranspirációt (a földfelszínröl történő párolgást és párologtatást) (Hayden 1998). Az éghajlaton túlmenően a biodiverzitásnak jelentős szerepe van például a termőtalaj védelmében is. Dombos illetve hegyes vidékeken az erdők kiirtása szinte azonnali és nagymértékủ erózióhoz vezet, az erdők vízgyüjtőkröl történő eltủnése árvizet és szintén eróziót eredményez (Sántha 1996).

Vagy ahogyan Batabyal és Nijkamp (2004) fogalmaznak: a környezeti externáliák természetükböl fakadóan térbeliek és gyakran határokon átnyúlóak. Ebböl következóen a regionális elemzéseknél ezen externáliák szélesebb nemzetközi vonatkozásainak mérlegelése elengedhetetlen.

${ }^{11}$ Amely, - mint ahogyan azt már korábban említettïk - jelenlegi tudásunk alapján észak-dél viszonylatban történik.

12 Jelenleg pontosan a természeti tőke elemeinek párhuzamos leromlását tapasztaljuk (Norgaard Bode 1998).

${ }^{13} \mathrm{~A}$ CNC a ,...környezeti erőforrások fontos környezeti funkciókat ellátó együttese, amely nem helyettesíthetó sem az ember által elóállított, sem pedig más természeti tőkével" (Buday-Sántha 2004, 16).

${ }^{14}$ A gyenge fenntarthatóság elmélete szerint a fenntarthatóság kritériumának teljesítéséhez elég, ha a két töketípus együttes értéke nem csökken - azaz, ha a természeti erőforrás megsemmisülésével legalább ugyanolyan értékủ mesterséges tỏke jön létre.

${ }^{15}$ Ilyenek a termelési tényezők egymástól való függetlensége és tetszőleges helyettesíthetősége (vö. a természeti tőkéről szóló résszel), mely leegyszerüsítések Kocsis (1999) szerint a neoklasszikus közgazdaságtan 19. században kialakuló módszertanából fakadnak.

${ }^{16}$ Ilyenek többek közt a természeti tökébe történő emberi beavatkozás esetén meglévő tiszta bizonytalanság, az ökoszisztémák nemlineáris változása és küszöbértékei, a visszafordíthatatlanság és a helyettesíthetőség hiánya (Málovics-Bajmócy 2007). Továbbá, az egyik potenciális gyakorlati problémára éppen a neoklasszikus közgazdaságtan világit rá, az irányzat szerint ugyanis a szigorúbb kömyezetvédelmi szabályozás a nemzetközi kereskedelemben versenyhátrányt eredményez (Boda-Pataki 1995).

${ }^{17}$ Utóbbi irodalom kifejezetten a technológiai rezsimek környezetbarát technológiák elterjedésével kapcsolatos vonatkozásait vizsgálja.

${ }^{18} \mathrm{Az}$ új institucionalista kutatások tematikájához jó támpontot nyújt az International Society for New Institutional Economic (INSIE) honlapja, ahol megtalálhatók a szervezet éves konferenciájának tematikái (jó néhány letölthetö elöadással) és a social science research networkben a „,new institutional economics" kifejezésre történő keresés eredményei. (Abstract Database Search Results - New Institutional Economics: http://papers.ssm.com/sol3/JELJOUR_Results.cfm?form_name-journalbrowse\&journal_id=641041.

${ }^{19}$ (http://www.isnie.org/programme2007.html\#)

${ }^{20}$ (http://www.isnie. org/isnie-2006.html)

21 (http://www. isnie.org/isnie-2005.html)

${ }^{22}$ Az irányzat kutatási irányai a fentieken túlmenően is potenciálisan sok mondanivalóval bírhatnak a fenntarthatóság szempontjából. Vizsgálja például az intézmények és a globalizáció, az intézmények és jogalkotás stb. viszonyát, de e kutatások fókusza nem a természet-gazdaság viszony.

${ }^{23}$ Itt most csupán a természet és a versenyképesség kapcsolatának szempontjából legfontosabb korlátot emeljük ki, a többihez, illetve Porter és a neoklasszikusok vitảjához lásd Boda-Pataki (1995).

${ }^{24}$ Ez alól pusztán Porter win-win tipusú megközelítése tekinthető kivételnek. 


\section{Irodalom}

Alcott, B. (2005) Jevons' paradox. - Ecological Economics. 54. 9-21. o.

Andersson, J.O.--Lindroth, M. (2001) Ecologically unsustainable trade. - Ecological Economics. 37. 113-122. o.

Bajmócy Z. (2007) Egyetemi üzleti inkubáció - Induló innovativ vállalkozások ösztönzése a helyi gazdaságfejlesztésben. Doktori disszertáció. SZTE-GTK KGI, Szeged.

Bajomi B. (2004) A biológiai sokféleség és jelentősége. -Kovász. 1-4. 7-14. o.

Batabyal, A.A.-Nijkamp, P. (2004) The environment in regional science: An eclectic review. - Papers in Regional Science. 83. 291-316. o.

Bekker Zs. (2000) Alapmüvek, alapirányzatok. AULA, Budapest.

Boda Zs.-Pataki Gy. (1995) A nemzetközi versenyképesség és a környezetügy. - Közgazdasági Szemle. 1. $66-94,0$.

Bourguignon, F.-Chakravarty, S.R. (2003) The measurement of multidimensional poverty. - Journal of Economic Inequality. 1. 25-49. o.

Brown, P.M.-Cameron, L.D. (2000) Survey - What can be done to reduce overconsumption? Ecological Economics. 32. 27-41. o.

Bruntland, G. (ed.) (1987) Our common future: The World Commission on Environment and Development. Oxford University Press, Oxford.

Buday-Sántha A. (2002) Környezetgazdálkodás. Akadémiai Kiadó, Budapest.

Buday-Sántha A. (2004) A természeti tóke és az agrárgazdaság szerepe a terïleti versenyképességben. PTE-KTK, Pécs.

Budd, L.-Hirmis, A.K. (2004) Conceptual Framework for Regional Competitiveness. - Regional Studies. 9. 1015-1028. o.

Carson, R.L. (1962) Silent Spring. Houghton Mifflin Company.

Chapin, F.S.-Zavaleta, E.S.--Eviner, V.T.-Naylor, R.L--Vitousek, P.M -Reynolds, H.L.-Hooper, D.U.Lavorel, S.-Sala, O.E.-Hobbie, S.E.-Mack, M.C.-Díaz, S. (2000) Consequences of Changing Biodiversity. - Nature. 405. 234-242. o.

Costanza, R.-d'Agre, R.-de Groot, R.-Farber, S.-Grasso, M.-Hannon, B.-Limburg, K.-Naeem, S.O'Neill, R.V.-Paruelo, H.-Raskin, R.G.-Sutton, P.-van der Belt, M. (1997) The value of the world's ecosystem services and natural capital. - Nature. 387. 253-260. o.

Csutora M.-Kerekes S. (2004) A környezetbarát válllalatirányitás eszközei. KJK, Budapest.

Daily, G.C.-Ehrlich, P.R. (1996) Socioeconomic Equity, Sustainability, and Earth's Carrying Capacity. - Ecological Applications. 4.991-1001. o.

Daily, G.C.--Ehrlich, P.R.--Ehrlich, A.H. (1995) Sociqeconomic Equity: A Critical Element in Sustainability. - Ambio. 1. 58-59. o.

Daily, G.C,-Söderqvist, T.-Aniyar, S.-Arrow, K.-Dasgupta, P.-Ehrlich, P.R.-Folke, C.- Jansson, AM.Jansson, B-O.--Kautsky, N.-Levin, S.-Lubchenco, J.-Mäler, K-G.-Simpson, D.-Starrett, D.-Tilman, D.-Walker, B. (2000) The Value of Nature and the Nature of Value.-Science. 289. 395-396. o.

Dosi, G.-Nelson, R.R. (1994) An Introduction to Evolutionary Theories in Economics. - Journal of Evolutionary Economics. 3. 153-172. o.

EC (1999) Sixth Periodic Report on the Social and Economic Situation and Development of Regions in the European Union. European Commission, Luxembourg.

EC (2001) A Sustainable Europe for a BetterWorld: A European Union Strategy for Sustainable Development. Commission's proposal to the Gothenburg European Council, Brussels.

EC (2005) Working together for growth and jobs. A new start for the Lisbon Strategy. Brussels.

Ehrlich, P.R-Wilson, E.O. (1991) Biodiversity Studies: Science and Policy. - Science. 253. 758-762. o.

Ekins, P. (2003) Identifying critical natural capital: Conclusions about critical natural capital. Ecological Economics. 2-3. 277-292. o.

Ekins, P.-Folke, C.-De Groot, R. (2003) Identifying critical natural capital - editorial. - Ecological Economics. 2-3. 159-163. 0.

ESDP (1999) European Spatial Development Perspective. Towards Balanced and Sustainable Development of the Territory of the European Union. Luxembourg

Gardiner, B.-Martin, R.-Tyler, P. (2004) Competitiveness, Productivity and Economic Growth across the European Regions. - Regional Studies. 9. 1045-1067. o.

Giljum, S.-Eisenmenger, N. (2004) North-South Trade and the Distribution of Environmental Goods and Burdens: a Biophysical Perspective. - Journal of Environment and Development. 1.73-100. o.

Gonezlik, A. (2004) Az élő természet adományai. - Kovász. 1-4. 15-43. o. 
Gowdy, J.M. (2004) A biodiverzitás értéke - Piacok, társadalom és ökológiai rendszerek. - Kovász. 1-4. 44-73. 0 .

Gustaffson, B. (1998) Scope and limits of the market mechanism in environmental management. Ecological Economics. 24. 259-274. o.

Gutés, M.C. (1996) The concept of weak sustainability. - Ecological Economics. 17. 147-156. o.

Hayden, B.P. (1998) Ecosystem Feedbacks on Climate at the Landscape Scale. - Philosophical Transactions of the Royal Society of London. 353. 5-18. o.

Interovernmental Panel on Climate Change (IPCC) (2007) The Physical Science Basis Summary for Policymakers. http://www.ipcc.ch/.

Kemp, R.-Schot, J.-Hoogma, R. (1998) Regime Shifts to Sustainability Through Strategic Niche Management. - Technology Analysis and Strategic Management. 2. 175-195. o.

Kerekes S.-Szlávik J. (2001) A környezeti menedzsment közgazdasági eszközei. KJK, Budapest.

Kitson, M.-Martin, R.-Tyler, P. (2004) Regional Competitiveness: An Elusive yet Key Concept? Regional Studies. 9. 991-999. o.

Kocsis T. (1999) A jövő közgazdaságtana? - Az ökológiai közgazdaságtan múltja, jelene és jövője az uralkodó neoklasszikus nézetek tükrében. - Kovász. 3. 131-164.o.

Krugman, P.-Obstfeld, M. (2003) Nemzetközi gazdaságtan. Panem Kiadó, Budapest.

Lengyel I. (2000) A regionális versenyképességről. - Közgazdasági Szemle. 47. 962-987 o.

Lengyel I. (2003) Verseny és terïleti fejlódés: Térségek versenyképessége Magyarországon. JatePress, Szeged.

Lengyel I.-Rechnitzer J. (2004) Regionális gazdaságtan. Dialóg Campus Kiadó, Budapest-Pécs.

Lukovics M. (2007) A lokális térségek versenyképességének elemzése. Doktori értekezés. SZTE Közgazdaságtani Doktori Iskola, Szeged.

Málovics Gy.-Bajmócy Z. (2007) A fenntarthatóság közgazdaságtani értelmezései. Konferenciaelőadás. 1. Országos Környezetgazdaságtani PhD.-konferencia. 2007, november 27. Budapest.

http://korny.uni-corvinus.hu/phd/1_kg_konf/malovics_bajmocy_phdkonf.pdf

Martin, R.L. (ed.) (2003) A Study on the Factors of Regional Competitiveness. A final report for The European Comission DG Regional Policy. University of Cambridge, Cambridge.

Meadows, D.H.-Meadows, D.D.--Randers, J.-Behrens, W. (1972) The Limits to growth: A report for the Club of Rome's Project on the Predicament of Man Kind. Universe Books, New York.

Millennium Ecosystem Assessment (MEA) (2005) Ecosystems and Human Well-being - Biodiversity Synthesis. World Resources Institute, Washington.

Nabhan, G.P.-Buchmann, S.L. (1997) Services Provided by Pollinators. - Daily, G.C. (ed.) Nature's Services - Societal Dependence on Natural Ecosystems. Island Press, Washington. 133-150. o.

Naylor, R.L.-Ehrlich, P.R. (1997) Natural Pest Control Services and Agriculture. - Daily, G.C. (ed.) Nature's Services - Societal Dependence on Natural Ecosystems. Island Press, Washington. 151-174. 0.

Nelson, R.R. (2006) Economic Development from the Perspective of Evolutionary Economic Theory. Working Papers in Technology Governance and Economic Dynamics. 2. Columbia.

Norgaard, R.B.-Bode, C. (1998) Next, the value of God, and other reactions. - Ecological Economics. 1. 37-39. 0 .

Novacek, M.J.-Cleland, E.E. (2001) The current biodiversity extinction event: Scenarios for mitigation and recovery. - PNAS. 1. 5466-5470. o.

Paavola, J. (2005) Seeking Justice: International Environmental Governance and Climate Change. Globalizations. 3. 309-322. o.

Paavola, J. (2007) Institutions and environmental governance: A reconceptualization. - Ecological Economics. 63. 93-103. o.

Paavola, J.-Adger, W.N. (2006) Fair adaptation to climate change. - Ecological Economics. 56. 594-609. o.

Pataki Gy. (2000) Az ökológiailag fenntartható vállalat. PhD. disszertáció tervezet. BKÁE Gazdálkodástudományi Kar Doktori Iskolája, Budapest.

Pimm, S.L. (1997) The value of everything. - Nature. 387. 231-232. o.

Porter, M.E. (1998) On Competition. The Free Press, New York.

Porter, M.E.-Kramer, M. (2006) The Link Between Competitive Advantage and Corporate Social Responsibility. - Harvard Business Review. December. 1-14. o.

Porter, M.E.-van der Linde, C. (1995) Toward a New Conception of the Environment-Competitiveness Relationship. - Journal of Economic Perspectives. 4. 97-118. o.

Rechnitzer J.-Smahó M. (2005) A humán eröforrások regionális sajátosságai az átmenetben. MTA Közgazdaságtani Intézet, Budapest.

Rees W.E. (1998) How should a parasite value its host? - Ecological Economics. 25. 49-52. o. 
Málovics György - Ván Hajnalka :

Az ökológiai fenntarthatóság és a regionális versenyképesség összefüggései.

Tér és Társadalom 22. évf. 2008/2. 21-40. p.

TÉT XXII. évf. 2008 - 2

Az ökológiai fenntarthatóság és a ...

Richter, R. (2005) The New Institutional Economics - Its Start, Its Meaning, Its Prospects. NIEHhistPaper.

Röpke, I. (1999) Analysis - The dynamics of willingness to consume. - Ecological Economics. 28. $399-420.0$.

Röpke, I. (2005) Consumption in ecological economics. - Entry prepared for the Internet Encyclopaedia of Ecological Economics. Department for Manufacturing Engineering and Management Technical University of Denmark, Denmark.

Sántha A. (1996) Környezetgazdálkodás - Részletes rész. Nemzeti Tankönyvkiadó, Budapest.

Sárvári É. (1979) Nitrogén és kén autrotrófia. - Növényéletton 1. Tankönyvkiadó, Budapest. 258-300. 0.

Schütz, H.-Moll, S.-Bringezu, S. (2004) Globalisation and the Shifting Environmental Burden. Material Trade Flows of the European Union - Which Globalisation is Sustainable? Wuppertal Institute for Climate, Environment, Energy, Wuppertal.

Schwartzman, D.W.-Volk, T. (1989) Biotic enhancement of weathering and the habitability of Earth. Nature. 340. 457-460. o.

Sen, A. (2003) A fejlödés, mint szabadság. Európa Könyvkiadó, Budapest.

Solow, R.M. (1997) Reply - Georgescu-Roegen versus Solow/Stiglitz. - Ecological Economics. 22. 267-269. o.

Spash, C.L. (1999) The Development of Environmental Thinking in Economics. - Environmental Values. 8. 413-435. o.

Stern, N. (2006) Stern Review on the Economics of Climate Change. http:/www.hmtreasury.gov.uk/independent reviews/stem_review_economics_climate_change/stem_review_report.cfm.

Stiglitz, J.E. (1997) Reply - Georgescu-Roegen versus Solow/Stiglitz. - Ecological Economics. 22. 269 270. o.

Streeten, P. (1981) First Things First - Meeting Basic Human Needs in Developing Countries. Oxford University Press, Washington.

Szabó K. (2003) Az új intézményi iskola avagy összefér-e a tudományos szigor a társadalmi referenciával? - Bekker Zs. (szerk.) Tantörténet és közgazdaságtudomány. AULA, Budapest. 356-386. o.

Szentes T. (2003) A fejlődéselméletek története és a történelmi valóság alakulása. - Bekker Zs. (szerk.) Tantörténet és közgazdaságtudomány. AULA, Budapest. 387-408. o.

Szlávik J. (2006) A nem fenntartható növekedés és a fenntartható fejlödés jellemzöi. - Bulla M. -Tamás P. (szerk.) Fenntartható fejlödés Magyarországon - Jövöképek és forgatókönyvek. ÚMK, Budapest. 196-211. o.

Thorbecke, E. (2006) The Evolution of the Development Doctrine, 1950-2005. - Research Paper. No. 2006/155. UNU-WIDER Economics Research.

Tilman, D. (2000) Causes, Consequences and Ethics of Biodiversity. - Nature. 405. 208-211. o.

Török Á. (1999) Verseny a versenyképességért. MeH Integrációs Stratégiai Munkacsoport, Budapest.

Turok, I. (2004) Cities, Regions and Competitiveness. - Regional Studies. 9. 1069-1083. o.

Turner, R.K. (1989) Sustainability, Resource Conservation and Pollution Control: An Overview. Turner, R.K. (ed.) Sustainabel Environmental Management. Principles and Practice. Belhaven Press, London. 1-25. o.

UNDP (1990) Human Development Report. Oxford University Press, New York.

UNDP-UNEP - World Bank-World Resources Institute (2000) People and Ecosystems - The Fraying Web of Life. WRI, Washington.

van den Bergh, J.C.J.M. (2003) Evolutionary Analysis of the Relationship between Economic Growth, Environmental Quality and Resource Scarcity. - Tinbergen Institute Discussion Paper. TI 2004-048/3.

van den Bergh, J.C.J.M. (2007) Evolutionary thinking in environmental economics. - Journal of Evolutionary Economics. 5. 521-549. o.

Vida G. (2001) Helyünk a bioszférában. Typotex, Budapest.

Woodruff, D.S. (2001) Declines of biomes and biotas and the future of evolution. - PNAS 10. 5471-5476. 0.

WWF (2004) Living Planet Report. World Wide Fund For Nature, Gland.

WWF (2006) Living Planet Report. World Wide Fund For Nature, Gland. 


\section{CONNECTIONS BETWEEN ECOLOGIC SUSTAINABILITY AND REGIONAL COMPETITIVENESS}

\section{GYÖRGY MÁLOVICS - HAJNALKA VÁN}

Both sustainability and regional competitiveness are in the centre of political and scientific attention. By now it is clear that enhancing competitiveness based on excessive exploitation of nature may be counterproductive by narrowing future social and economic alternatives.

In our study we highlight the basic characteristics of the relationship of natural capital and regional competitiveness. Therefore we analyze the special literature dealing with the interdependence of ecological and economic systems from the aspect of regional competitiveness. Afterwards we explore whether these scientific results have became part of economic disciplines that have relevant message regarding natural capital and regional competitiveness. These surveyed bodies of thinking are neoclassical economics, development economics, evolutionary economics, (new) institutional economics and the Portarian new economics of competition. We conclude that the relationship of natural capital and regional competitiveness is a rather neglected research area. 